\title{
Effect of the Harvest Date on the Chemical Composition of Patauá (Oenocarpus bataua Mart.) Fruits from a Forest Reserve in the Brazilian Amazon
}

\author{
Raimundo Silva de Souza, ${ }^{1}$ Jerusa Souza Andrade, ${ }^{1,2}$ and Suely de Souza Costa ${ }^{3}$ \\ ${ }^{1}$ Departamento de Tecnologia de Alimentos, Instituto Nacional de Pesquisas da Amazônia, 69060-001 Manaus, AM, Brazil \\ ${ }^{2}$ Coordenação de Pesquisa, Universidade Nilton Lins, 69058-030 Manaus, AM, Brazil \\ ${ }^{3}$ Departamento de Ciências Agrárias, Instituto Nacional de Pesquisas da Amazônia, caixa postal 478, 69060-001 Manaus, AM, Brazil
}

Correspondence should be addressed to Jerusa Souza Andrade, andrade@inpa.gov.br

Received 5 December 2011; Revised 2 March 2012; Accepted 3 March 2012

Academic Editor: Mohamed Fawzy Ramadan

Copyright ( $) 2012$ Raimundo Silva de Souza et al. This is an open access article distributed under the Creative Commons Attribution License, which permits unrestricted use, distribution, and reproduction in any medium, provided the original work is properly cited.

\begin{abstract}
This study aims to evaluate the effect of harvest date on the chemical composition of patauá (Oenocarpus bataua Mart.). Fruits were harvested monthly during the harvest season (June-December, 2009) from native plants in the Adolpho Ducke Forest Reserve located in Manaus, Amazonas, Brazil. The patauá was assessed for pulp yield and chemical composition. Variations in the bunch size, quantity of fruits, chemical constituents and calories occur throughout the season. The pulp yield showed two plateaus, the first from June to September and the second from October to December. The pulp yield was highest in the last three months, the amount of added water equilibrates the total solids and the lipids stood out as the major chemical constituent. At the end of harvest, the patauá became dry and oily and less fibrous. Despite the significant differences, considering that the pulp yield and solids content can be standardized by added water, the entire period of the season may be indicated for the pataua can be periodically collected and considered as a high-energy food for the people of Amazon.
\end{abstract}

\section{Introduction}

The Amazon has a great diversity of fruit species, and many of them are domesticated and present importance in the primary sector and commerce $[1,2]$. Various palms native to Amazonia and other tropical regions of Latin America have been the subject of research and development and require sustainable extractivism [3]. This activity allows the exploitation of products from the forest and of biodiversity valorization $[4,5]$.

In the Amazon, the fruits of the palm trees such as açaí (Euterpe oleracea and E. precatoria), bacaba (Oenocarpus bacaba), buriti (Mauritia flexuosa), inajá (Maximiliana mari$p a$ ), and patauá (Oenocarpus bataua) have similarities in the process of production, consumption, and consistency of pulps [2]. Before the pulping, all fruits should remain immersed in water slightly tepid to softening of the edible portion. Then, in pulping process is necessary the addition of the water. In the pulper occurs the scraping/pressing of the fruit (the edible portion is released and fragmented) followed by sieving (retention of the seeds and fragments non-crushed) and finally getting the pulp completely homogenized. This highly dense juice is popularly known as pulp or "wine" and consumed, added or not, of the manioc flour, "tapioca" flour, salt, or sugar $[4,5]$.

The other similarity between them is due to high content of unsaturated fatty acid in buriti, tucumã (Astrocaryum vulgare), inajá, mari (Poraqueiba paraensis), and patauá [6]. The color, nutritional value, and content of the bioactive substances vary due to differences in the chemical composition [7]: carotenoids in buriti [8]; anthocyanins in açaí (E. oleracea) $[7,9]$; tocopherol in buriti and patauá [10].

Amazonian palm fruits are rich in fat. They have a fatty acid profile that may be beneficial in relation to risk of coronary heart disease. These fruits also contain other potentially cardioprotective constituents including tocopherol. Thus, they are good sources of unsaturated fatty acids and tocopherols [6]. Patauá pulp is highly oleaginous, and its fatty 
acid composition is very similar to the ones of healthy oils, such as olive oil [10].

Among the Amazonian fruits we highlight the patauá. It is a fruit of a palm-stemmed. This palm tree has a height from 4.3 to 26 meters and a diameter of 15 to $45 \mathrm{~cm}$. The fruits are ovoid, size from 2.5 to $3.5 \mathrm{~cm}$, length from 2.0 to $2.5 \mathrm{~cm}$ in diameter, and color dark violet or purple $[11,12]$.

The pataua is principally used for pulp production. Besides the pulp, several researchers report that in the Amazon basis, traditionally the pataua oil is extracted and used for: preparation of food (fried foods, salad dressing, and meat preservative); cosmetic (prevent dandruff and hair loss); in traditional medicine (the oil is used to treat tuberculosis, ointment, decongestant, emollient, expectorant, and stimulant to bowel movements). The roots of the palm tree are used to combat diarrhea, worms, headache, and stomacal disorders [2, 12-14].

The pataua is harvested from native plants located in the forest according to the extractive system [15], and the pulp (principal use) and oil (minor use) are obtained from the fruit. The pulp is used as dense juice, and the oil is traditionally used in medicine, cosmetics, and foods. For oil extraction, the fruits are and heated with boiling water. The residue is discarded, and the liquid fraction (oil and water) is cooled. After decanting, the oil is separated from the aqueous fraction by density differences $[13,16]$.

The pulp is obtained from the pulper (powered by electricity), but the manual system is still used. The manual system consists of pressing the fruit in the container with water to release and grind the edible portion. Subsequently, the pulp is passed through a sieve. In the pulper, the process is discontinuous (batch). The fruits are smashed with water (added gradually). The pulp passes through sieve (disc kept inside in the pulper) and comes already mixed. The residue (seed and skin) is retained within the device and is subsequently removed. The amount of water is variable and depends on the traditional knowledge, the fruit maturation, and the yield desired.

Overall, the maturation of the fruit is important in terms of sensory, nutritional, and technological characteristics. The optimal harvesting point coincides with the maximum of chemicals constituents, which are responsible for these attributes. The dimension of the crop time allows the estimation of time required for dispersion of the species (dispersers natural) and for harvest. Thus, this estimate is the basis for the adoption of public policies to preserve the species and food availability.

In Brazil [17], Ecuador [15], and Colombia [18], the patauá phenophases were studied. With differences in periods and ecosystems, it was found that fruit production occurs throughout the year. However, besides the production of fruits is also important to evaluate the chemical composition of fruits throughout the season.

In Brazil, specifically in the Adolpho Ducke Forest Reserve, the same used in this study, was studied the phenology palm tree patauá, correlating phenological data (ten phenophases) with meteorological variables. Rainfall and sunshine were the variables with high discriminatory power in the formation of the main components. The bunches with ripe fruits occurred throughout the year, but in larger quantities from April to December [17].

In Colombia were studied the reproductive phenology and productivity patauá [18]. A phenological cycle the population level (since the appearance of flower buds to fallen fruit) takes approximately four years. Peak production of ripe fruits in a population occurred every 34 months. The behavior of the phenology of pataua is continuous and cycli$\mathrm{cal}$, with an approximate duration of four years. The low synchrony and the temporality of the production cycle indicated that there is no relationship between precipitation and phenology. The authors conclude that, to implement management programs and utilization of the species, it is important to consider that the production of mature fruits is not continuous and is presented for 22 months, alternating with 12 -month supply void. Therefore, the sustainable management of forests through the periodic use can lead to food to local communities and even so, promote the conservation of ecosystems.

The importance of the studies on the pataua is to provide information on: biodiversity valorization; discloseure of the non-conventional oleaginous fruits; inclusion of this highenergy food in the specific diets; valorization of the family farms and the sustainable development of the Amazonian biodiversity; estimating the best harvest date. Thus, this study aims to evaluate the influence of the harvest date on the chemical composition of the pataua from the forest reserve located in the Amazon.

\section{Material and Methods}

2.1. Fruits Obtention. The fruits of patauá (Oenocarpus bataua Mart.) were harvested from native plants of the Adolpho Ducke Forest Reserve. This reserve belongs to the National Institute for Amazonian Research (Instituto Nacional de Pesquisas da Amazônia (INPA)) and it is located in Manaus, Amazonas, Brazil. It is situated along Highway 010 Manaus, Itacoatiara $(\mathrm{km} \mathrm{26})$ and is bordered with the suburban areas of Manaus city. This reserve is situated between the coordinates $59^{\circ} 52^{\prime} 40^{\prime \prime}$ and $59^{\circ} 58^{\prime} 00^{\prime \prime}$, west longitude and $03^{\circ} 00^{\prime} 00^{\prime \prime}$ and $03^{\circ} 08^{\prime} 00^{\prime \prime}$, south latitude [19].

The reserve covers a continuous area with 10,072 hectares. The upland soils are interspersed with areas of lowland soils, and the natural vegetation is fully preserved. The pataua is found in the humid areas. The plants grow in high-density stands, some with about 100 plants $[17,19,20]$. The harvest was done in a population of 86 plants, located near one of the internal supervisory stations, called "Sabiá III."

Seven bunches (one bunch per month) of patauá (ripe fruits) were harvested from various plants during the harvest season (from June to December) of 2009 and the interval between each harvest was 30 days. Bunches were cut with a knife, carefully placed in the truck, and immediately transported to the Food Technology Department of the INPA, where this work was carried.

2.2. Obtention of the Pulp. The bunches, rachis fruits, and pulp were weighed, and the data were used to estimate the 
Table 1: Physical characteristics of the patauá (Oenocarpus bataua Mart.) from the Adolpho Ducke Forest Reserve localized in Manaus, Amazonas, Brazil, and harvested at different times during the season (2009).

\begin{tabular}{|c|c|c|c|c|c|c|c|}
\hline \multirow{2}{*}{ Harvest date } & \multicolumn{7}{|c|}{ Physical characteristics } \\
\hline & 1 & 2 & 3 & 4 & 5 & 6 & 7 \\
\hline June & 1.13 & 18.20 & 4.70 & 13.50 & 7.61 & 56.37 & 41.81 \\
\hline July & 1.18 & 19.55 & 6.91 & 12.64 & 7.13 & 56.41 & 36.47 \\
\hline August & 1.32 & 23.77 & 9.00 & 14.77 & 8.33 & 56.40 & 35.04 \\
\hline September & 1.06 & 18.12 & 5.00 & 13.12 & 7.44 & 56.71 & 41.06 \\
\hline October & 1.12 & 14.50 & 4.50 & 10.00 & 7.93 & 79.30 & 54.69 \\
\hline November & 1.11 & 16.00 & 6.00 & 10.00 & 9.95 & 79.50 & 49.69 \\
\hline December & 1.37 & 19.30 & 6.80 & 12.50 & 9.50 & 76.00 & 49.22 \\
\hline Average & 1.17 & 18.49 & 6.13 & 12.36 & 8.27 & 65.18 & 44.00 \\
\hline $\mathrm{SD}$ & 0.12 & 2.94 & 1.70 & 1.78 & 1.07 & 11.71 & 7.35 \\
\hline CV (\%) & 9.93 & 15.92 & 26.04 & 14.37 & 12.95 & 17.79 & 16.71 \\
\hline
\end{tabular}

1: bunch lenght $(\mathrm{m})$, 2: whole bunch weight $(\mathrm{Kg}), 3$ : rachis weight $(\mathrm{Kg}), 4$ : fruits weight $(\mathrm{Kg}), 5$ : pulp weight $(\mathrm{Kg}), 6$ : pulp yield (\%) from the fruits, 7: pulp yield $(\%)$ from the bunche, SD: standard deviation, CV: coefficient of variation, means followed by the same letters within each column are not statistically different $(P<0.05$, Tukey test).

pulp yield. The length of the bunch was measured with a tape measure.

In this study we used two methods of pulping: the system with mechanic pulper (electrically powered), thus obtaining the pulp P1; the manual system to obtaining the pulp P2. For both we used the same sequence of softening, moisturizing, pulping, and sieving. In this study the process (harvest and pulping) was aided by a person who knows and works with the extraction and sales of pulp of patauá.

The fruits were selected, weighed, washed, sanitized by immersion for 15 minutes in $0.02 \%$ sodium hypochlorite solution and rinsed with water. For the softening/moisturizing the fruits were separated into batches $( \pm 5 \mathrm{~kg}$ each $)$, transferred to plastic containers (20 liters), and kept immersed for 30 minutes in water at $45^{\circ} \mathrm{C}$. Then they were drained and pulped by two methods to get the pulp P1 (mechanical) and P2 (manual).

For the P1 (mechanical pulping) was used the pulper (stainless steel, electric-powered, capacity for $10 \mathrm{~kg}$ ) with discontinuous system and each batch with $\pm 5 \mathrm{~kg}$. The process consisted of two sequential steps. During the first stage the equipment operated for three minutes with only the fruits. Then the operation continued for more seven minutes, but with the gradual addition of the water (distilled water). The total time for the process was 10 minutes (three minutes with only the fruits and then for more seven minutes after the water has been added). When out of the machine the pulp passed through the sieve (perforated disc at the bottom of the output of the pulper). The pulp was collected, homogenized, packed in plastic bags (500 g each), frozen, and stored in a freezer at $-19^{\circ} \mathrm{C}$.

In parallel, a part of the fruits was pulped using the manual method (still used in the Amazon region). The process consisted of the friction of the fruits in container (stainless steel pot), but without the addition of water. This pulp was also packaged in plastic bags. The pulp P2 (obtained with the manual system and no water added) was collected, homogenized, packed in plastic bags, and analyzed immediately.
2.3. Chemical Composition. The pulp P1 (obtained in the pulper and with addition of the water) was evaluated for moisture content and chemical composition. The pulp P2 (obtained with the manual system and no water added) was evaluated only on the moisture and dry matter. All determinations were performed in triplicate following the methods described by Ranganna [21]. The results are expressed as fresh and dry basis and reported as mean values \pm standard deviation.

The moisture content was obtained by drying in an oven (with forced air) at $65^{\circ} \mathrm{C}$ until constant weight, the dry matter by difference and the ash by incineration in a muffle furnace for four hours at $550^{\circ} \mathrm{C}$. The lipids were extracted with hexane for six hours in a Soxhlet apparatus. Total nitrogen was determined by micro-Kjeldahl method and converted to protein by use of the 6.25 factor. Fiber was determined using the Tecnal (TE-149 model) equipment. For acidic and alkaline hydrolysis, the $0.255 \mathrm{~N} \mathrm{H}_{2} \mathrm{SO}_{4}$ and $0.313 \mathrm{~N} \mathrm{NaOH}$ solutions were used.

The carbohydrates were estimated by difference. Gross energy (calories) was calculated using the AtVater method and the following values: protein $=4 \mathrm{kcal} / \mathrm{g}$, lipids $=9 \mathrm{kcal} / \mathrm{g}$, and carbohydrate $=4 \mathrm{kcal} / \mathrm{g}$.

2.4. Statistical Analysis. The data were subjected to analysis of variance, and the Tukey test of means was applied with 5\% of probability using ASISTAT software, version 7.2 [22].

\section{Results and Discussion}

3.1. Physical Characteristics. The results of the physical assessments are shown in Table 1. The bunch size (weight and length) and quantity of fruits showed variations throughout the season, and the highest values were detected in the third harvest (August).

The variations show the occurrence of diversity among the native plants, as previously reported [13, 15, 17]. The pataua showed large bunches, and the fruits are located in 
TABle 2: Moisture content of the patauá (Oenocarpus bataua Mart.) fruits harvested in the Adolpho Ducke Forest Reserve, in Manaus, Amazonas, Brazil.

\begin{tabular}{lcr}
\hline Harvest date & \multicolumn{1}{c}{ Mechanic } \\
\hline June & $42.19 \pm 0.28 \mathrm{a}$ & $83.92 \pm 0.12 \mathrm{a}$ \\
July & $39.84 \pm 0.26 \mathrm{~b}$ & $87.46 \pm 0.33 \mathrm{a}$ \\
August & $40.55 \pm 0.57 \mathrm{~b}$ & $85.34 \pm 0.71 \mathrm{a}$ \\
September & $39.63 \pm 0.35 \mathrm{~b}$ & $84.69 \pm 0.28 \mathrm{~b}$ \\
October & $36.93 \pm 0.42 \mathrm{c}$ & $81.09 \pm 0.40 \mathrm{c}$ \\
November & $33.33 \pm 0.72 \mathrm{~d}$ & $81.61 \pm 0.17 \mathrm{c}$ \\
December & $33.38 \pm 0.33 \mathrm{~d}$ & $81.29 \pm 0.59 \mathrm{c}$ \\
Average & 38.06 & 83.54 \\
SD & 3.28 & 2.49 \\
CV $(\%)$ & 8.6 & 2.98 \\
\hline
\end{tabular}

Means followed by the same letters within each column are not statistically different $(P<0.05$, Tukey test).

TABle 3: Chemical composition of the patauá (Oenocarpus bataua Mart.) fruits harvested in the Adolpho Ducke Forest Reserve, in Manaus, Amazonas, Brazil.

\begin{tabular}{lcccc}
\hline Harvest date & Lipids & Chemical constituents $\left({\left.\mathrm{g} 100 \mathrm{~g}^{-1} \text { of the dry matter }\right)}^{\text {Psotein }}\right.$ \\
\hline June & $58.88 \pm 0.68 \mathrm{de}$ & $6.72 \pm 0.19 \mathrm{a}$ & $4.08 \pm 0.04 \mathrm{f}$ & $1.89 \pm 0.11 \mathrm{ab}$ \\
July & $57.26 \pm 0.45 \mathrm{e}$ & $6.69 \pm 0.20 \mathrm{a}$ & $4.87 \pm 0.02 \mathrm{e}$ & $1.61 \pm 0.03 \mathrm{~b}$ \\
August & $58.90 \pm 0.39 \mathrm{~d}$ & $5.48 \pm 0.19 \mathrm{~b}$ & $5.92 \pm 0.02 \mathrm{c}$ & $1.89 \pm 0.10 \mathrm{ab}$ \\
September & $51.94 \pm 0.57 \mathrm{f}$ & $7.05 \pm 0.45 \mathrm{a}$ & $6.17 \pm 0.13 \mathrm{~b}$ & $2.23 \pm 0.18 \mathrm{a}$ \\
October & $60.58 \pm 0.40 \mathrm{c}$ & $4.60 \pm 0.18 \mathrm{bc}$ & $6.79 \pm 0.06 \mathrm{a}$ & $1.63 \pm 0.32 \mathrm{~b}$ \\
November & $70.21 \pm 1.05 \mathrm{a}$ & $3.87 \pm 0.42 \mathrm{c}$ & $5.31 \pm 0.13 \mathrm{~d}$ & $1.74 \pm 0.05 \mathrm{ab}$ \\
December & $63.58 \pm 0.11 \mathrm{~b}$ & $4.37 \pm 0.29 \mathrm{c}$ & $6.19 \pm 0.12 \mathrm{~b}$ & $1.86 \pm 0.32 \mathrm{ab}$ \\
Average & 60.19 & 5.54 & 5.62 & 1.84 \\
SD & 5.39 & 1.26 & 0.88 & 0.26 \\
CV $(\%)$ & 9.0 & 22.81 & 15.70 & 14.1 \\
\hline
\end{tabular}

SD: standard deviation, CV: coefficient of variation, means followed by the same letters within each column are not statistically different $(P<0.05$, Tukey test).

the middle portion of the rachis. The pulp yield showed two plateaus, the first from June to September and the second from October to December. The pulp yield was highest in the last three months.

For pulping, the quantities of the fruit and the water were variable, according to the traditional knowledge. Even with difference in the characteristics of the fruit, they are able to obtain uniform pulp density. Despite variations (weights of fruits and pulp yield) during the season, the amount of added water equilibrates the total solids (dry matter). The amount of water to be added depends on the desired consistency, which was previously stipulated. Moving the pulp between the fingers (sensory) they evaluate and equalize the consistency of the pulp. In the Amazon, this is the normal process used by sellers of the patauá. Thus, the results in dry basis were used to evaluate the effect of harvest time.

3.2. Chemical Composition. The results of the moisture and the other chemical constituents are shown in Tables 2 and 3, respectively. The chemical constituents (expressed in dry matter) showed variations and with a significant difference between harvest dates. The moisture and fiber decreased during the season, while the protein and lipids increased. Minerals, represented by ash were relatively constant throughout the study period.

In addition to the higher content of proteins, at the end of harvest, the patauá became dry and oily and less fibrous. (Although not measured, knowledge of the depulper suggests the retention of the fibers in the machine sieve whose mesh is small, since it was designed for the pulping of açaí). Throughout the year, the region is characterized by two climatic periods: rainy (winter) and nonrainy season (summer) and beginning of fruit harvest (June) occurred after the end of the rainy season.

The moisture content (average $=38.06 \%$ ) of the pulp (P2) from native plants of the Adolpho Ducke Forest Reserve is similar to patauá coming from the Colombia (36.9\%) [23]. Natural pulp, obtained without water, is not obtained and consumed.

Despite the significant differences, considering that the pulp yield and total solids content can be standardized by added water, the entire period of the season may be indicated for the patauá can be collected. 
TABle 4: Nutritional value of the patauá (Oenocarpus bataua Mart.) fruits from the Adolpho Ducke Forest Reserve localized in Manaus, Amazonas, Brazil, and harvested at different times during the season.

\begin{tabular}{lcccc}
\hline \multirow{2}{*}{ Harvest date } & Lipids & Energy (Kcal) and nutritional constituents $\left(\mathrm{g} 100 \mathrm{~g}^{-1}\right.$ of fresh pulp) & Carbohydrates & Energy \\
\hline June & $9.47 \pm 0.11 \mathrm{~d}$ & $0.66 \pm 0.01 \mathrm{e}$ & $4.57 \mathrm{~b}$ & $106.13 \mathrm{c}$ \\
July & $6.92 \pm 0.05 \mathrm{~g}$ & $0.61 \pm 0.01 \mathrm{f}$ & $3.97 \mathrm{c}$ & $80.59 \mathrm{e}$ \\
August & $8.63 \pm 0.06 \mathrm{e}$ & $0.87 \pm 0.01 \mathrm{~d}$ & $4.08 \mathrm{c}$ & $97.48 \mathrm{c}$ \\
September & $7.95 \pm 0.09 \mathrm{f}$ & $0.94 \pm 0.02 \mathrm{c}$ & $5.00 \mathrm{a}$ & $95.30 \mathrm{~d}$ \\
October & $11.46 \pm 0.08 \mathrm{c}$ & $1.28 \pm 0.01 \mathrm{a}$ & $4.99 \mathrm{a}$ & $128.23 \mathrm{~b}$ \\
November & $12.90 \pm 0.19 \mathrm{a}$ & $0.98 \pm 0.02 \mathrm{c}$ & $3.48 \mathrm{~d}$ & $133.94 \mathrm{a}$ \\
December & $11.89 \pm 0.02 \mathrm{~b}$ & $1.16 \pm 0.02 \mathrm{~b}$ & $4.49 \mathrm{~b}$ & $126.62 \mathrm{~b}$ \\
Average & 9.89 & 0.93 & 4.37 & 110.18 \\
SD & 2.12 & 0.23 & 0.52 & 20.59 \\
CV $(\%)$ & 21.43 & 25.09 & 11.84 & \\
\hline
\end{tabular}

SD: standard deviation, CV: coefficient of variation, means followed by the same letters within each column are not statistically different $(P<0.05$, Tukey test).

According to Miller [15], overexploitation of this species does not appear to be a problem. Nevertheless the potential for overharvesting exists and may also negatively affect frugivore populations, mammal and bird populations during food shortage periods, usually during transition from wetto-dry seasons. Terrestrial rodent populations are especially important to dispersing and consuming the patauá.

As pataua is not alone and main meal, the disclosure of its importance in energy intake can increase the ecological awareness that it is a species that deserves to be properly exploited to improve the diet of human populations located in areas, where it occurs naturally.

3.3. Nutritional Value. The results of the nutritional value of pataua pulp are shown in Table 4. As the consumer purchases the pulp obtained in the puper (with water added) and standardized empirically, the result was also expressed as fresh pulp. Adding water (during the pulping process) increased the juiciness and decreased the amount of total solids. These solids (12.54-18.91\%) are important because they contain chemical compounds with nutritional and functional value. The results of the nutritional components are higher than those found in açaí [24].

Results of the pulp P2 (without water) show that the patauá is not a juicy fruit. The mesocarp (pulp) and exocarp (skin) is oily and fibrous, respectively, and the pataua is not consumed as the flesh fruit. The obtention of the pulp from the pataua is similar to the others palm fruits such as açaí, buriti, inajá, and bacaba: it requires softening and moisturizing (immersion into the tepid water) in the first step and then, addition of water during the depulping. Thus, in the Brazilian legislation, the patauá is classified as tropical fruit, whose pulp can be incorporated with water.

The pataua is highly caloric, and the results are higher than buriti [25] and bocaiúva (Acrocomia aculeata, Jacq. Lodd. [26]). Throughout the season, there was an increase of lipids, and consequently, in the energy value. More than half (60.19\%) of the chemical constituents are lipids, showing patauá as a rich source of energy belong to the so-called oleagi- nous crops. On balance the calories, the contributions of lipids, carbohydrates, and proteins were $80.6,16 \%$ and $3.4 \%$, respectively.

In all dates of harvest, the pulp of patauá (from the pulper, with water added) exhibited the following characteristics: dense consistency; high content of total solids; the appearance of an emulsion; purplish color and interspersed with small spots of the brown color; taste with equilibrium between sweet and acid, without the predominance of any of them.

\section{Conclusion}

Variations in the bunch size, quantity of fruits, chemical constituents, and calories occur throughout the season. The pulp yield showed two plateaus, the first from June to September and the second from October to December. The pulp yield was highest in the last three months, the amount of added water equilibrates the total solids, and the lipids stood out as the major chemical constituent. At the end of harvest, the patauá became dry and oily and less fibrous.

Despite the significant differences, considering that the pulp yield and total solids content can be standardized by added water, the entire period of the season may be indicated for the patauá can be collected and considered as a high-energy food for the people of Amazon.

\section{References}

[1] C. R. Clement, M. Cristo-Araújo, G. C. Eeckenbrugge, A. A. Pereira, and D. Picanço-Rodrigues, "Origin and domestication of native Amazonian crops," Diversity, vol. 2, no. 1, pp. 72-106, 2010.

[2] R. Revilla, Plantas da Amazônia: oportunidades econômicas sustentáveis, SEBRAE/INPA, Manaus, Brazil, 2001.

[3] C. R. Clement, E. Leiras-Pérez, and J. Van Leeuwen, "O potencial das palmeiras no Brasil: acertos e fracassos das últimas décadas," Agrociencias, vol. 9, no. 1-2, pp. 67-71, 2005.

[4] J. Major, C. R. Clement, and A. DiTommaso, "Influence of market orientation on food plant diversity of farms located on 
Amazonian Dark Earth in the region of Manaus, Amazonas, Brazil," Economic Botany, vol. 59, no. 1, pp. 77-86, 2005.

[5] N. C. Kawa, D. Rodrigues, and C. R. Clement, "Useful species richness, proportion of exotic species, and market orientation on Amazonian dark earths and oxisols," Economic Botany, vol. 65, no. 2, pp. 169-177, 2011.

[6] A. M. Da Cruz Rodrigues, S. Darnet, and L. H. M. Da Silva, "Fatty acid profiles and tocopherol contents of buriti (mauritia flexuosa), patawa (oenocarpus bataua), tucuma (astrocaryum vulgare), mari (poraqueiba paraensis) and Inaja (Maximiliana Maripa) fruits," Journal of the Brazilian Chemical Society, vol. 21, no. 10, pp. 2000-2004, 2010.

[7] G. M. Santos, G. A. Maia, P. H. M. Souza, J. M. C. Costa, R. W. Figueiredo, and G. M. Prado, "Correlação entre atividade antioxidante e compostos bioativos de polpas comerciais de açaí (Euterpe oleracea Mart)," Archivos Latinoamericanos de Nutricion, vol. 58, no. 2, pp. 187-192, 2008.

[8] J. G. R. Mariath, M. C. C. Lima, and L. M. P. Santos, "Vitamin A activity of buriti (Mauritia vinifera Mart) and its effectiveness in the treatment and prevention of xerophthalmia," American Journal of Clinical Nutrition, vol. 49, no. 5, pp. 849853, 1989.

[9] J. D. C. Pessoa, M. Arduin, M. A. Martins, and J. E. U. de Carvalho, "Characterization of Açaí (E. oleracea) fruits and its processing residues," Brazilian Archives of Biology and Technology, vol. 53, no. 6, pp. 1451-1460, 2010.

[10] S. H. Darnet, L. H. M. Silva, A. M. C. Rodrigues, and R. T. Lins, "Nutritional composition, fatty acid and tocopherol contents of buriti (Mauritia flexuosa) and patawa (Oenocarpus bataua) fruit pulp from the Amazon region," Ciência e Tecnologia de Alimentos, vol. 31, no. 2, pp. 488-491, 2011.

[11] L. A. Núñez-Avellaneda and R. Rojas-Robles, "Biología reproductiva y ecología de la polinización de la palma milpesos Oenocarpus bataua en los Andes Colombianos," Caldasia, vol. 30, no. 1, pp. 101-125, 2008.

[12] I. P. A. Miranda, A. Rabelo, C. R. Bueno, E. M. Barbosa, and M. N. S. Ribeiro, Frutos de palmeiras da Amazônia, MCT/INPA, Manaus, Brazil, 2001.

[13] M. Balick, Jessenia and Oenocarpus: neotropical oil palms worthy of domestication, FAO, Rome, Italy, 1988.

[14] Z. A. Mena, "Influence of the Huaorani on the conservation of (Oenocarpus bataua), Arecaceae in Yasuni National Park and Biosphere Reserve Amazonian Ecuador," Journal of Ecology and Application, vol. 10, no. 2, pp. 83-90, 2006.

[15] C. Miller, "Fruit production of the ungurahua palm (Oenocarpus batua subsp. bataua, Arecaceae) in an indigenous managed reserve," Economic Botany, vol. 56, no. 2, pp. 165-176, 2002.

[16] D. A. P. G. Silva, L. H. O. Wadt, and C. Ehring, Ecologia e manejo de patauá (Oenocarpus bataua Mart) para produção de frutos e óleo, EMBRAPA, Rio Branco, Brazil, 2004.

[17] R. R. Ruiz and J. C. Alencar, "Comportamento fenológico da palmeira patauá (Oenocarpus bataua) na reserva florestal Adolpho Ducke, Manaus, Amazonas, Brasil," Acta Amazonica, vol. 34, no. 4, pp. 553-558, 2004.

[18] L. Cifuentes, F. Moreno, and D. A. Arango, "Fenología reproductiva y productividad de Oenocarpus bataua (Mart.) en bosques inundables Del Chocó Biogeográfico, Colombia," Biota Neotropica, vol. 10, no. 4, 2010.

[19] J. C. Alencar, "Fenologia de cinco espécies arbóreas tropicais de Sapotaceae correlacionada a variáveis climáticas na Reserva Ducke," Acta Amazonica, vol. 24, no. 3/4, pp. 161-182, 1994.

[20] F. Moussa, I. P. A. Miranda, and F. Kahn, Palmeiras no Herbário do INPA, INPA/ORSTOM, Manaus, Brazil, 1994.
[21] S. Ranganna, Handbook of Analysis and Quality Control for Fruit and Vegetable Products, Tata McGraw-Hill, New Delly, India, 1986.

[22] F. A. S. Silva and C. A. V. Azevedo, "Versão do programa computacional Assistat para o sistema operacional Windows," Revista Brasileira de Produtos Agroindustriais, vol. 4, no. 1, pp. 71-78, 2002.

[23] M. E. Collazos and M. Mejía, "Fenología y postcosecha de milpesos Jessenia bataua (Mart.) Burret," Acta Agronomica, vol. 38, no. 1, pp. 53-63, 1988.

[24] D. Alexandre, R. L. Cunha, and M. D. Hubinger, "Conservação do açaí pela tecnologia de obstáculos," Ciência e Tecnologia de Alimentos, vol. 24, no. 1, pp. 114-119, 2004.

[25] M. Tavares, S. Aued-Pimentel, L. C. A. Lamardo, N. C. Campos, L. I. F. Jorge, and E. Gonzalez, "Composição química e estudo anatômico dos frutos de buriti do Município de Buritizal, Estado de São Paulo," Revista do Instituto Adolfo Lutz, vol. 62, no. 3, pp. 227-232, 2003.

[26] M. I. L. Ramos, M. M. RamosFilho, P. A. Hiane, J. A. Braga Neto, and E. M. A. Siqueira, "Qualidade nutricional da polpa de bocaiúva Acrocomia aculeata (Jacq.) Lodd," Ciência e Tecnologia de Alimentos, vol. 28, pp. 90-94, 2008. 


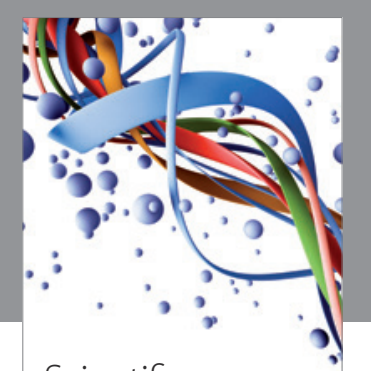

Scientifica
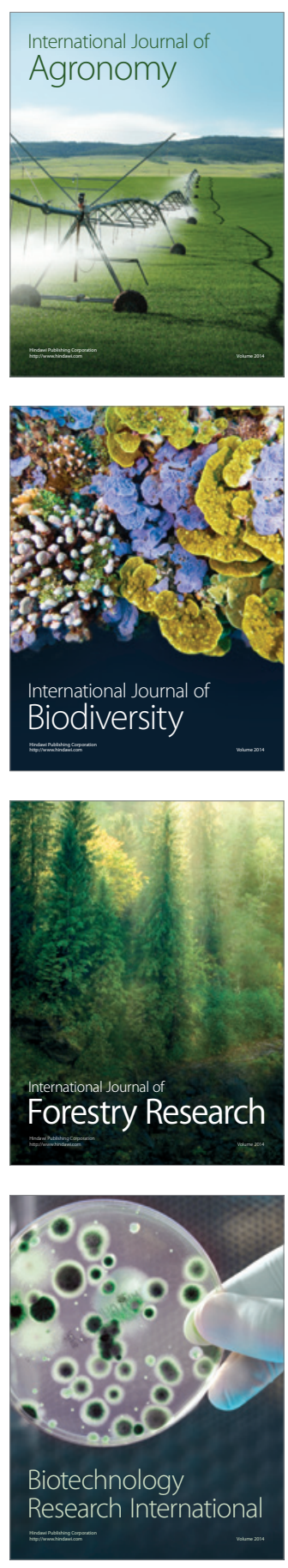
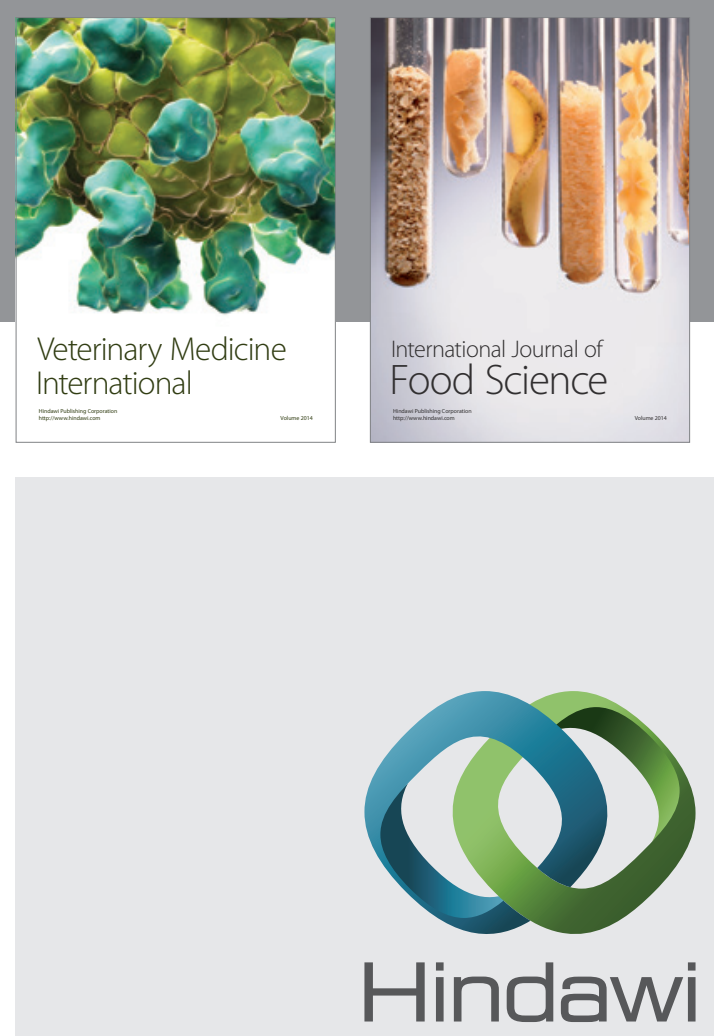

Submit your manuscripts at

http://www.hindawi.com
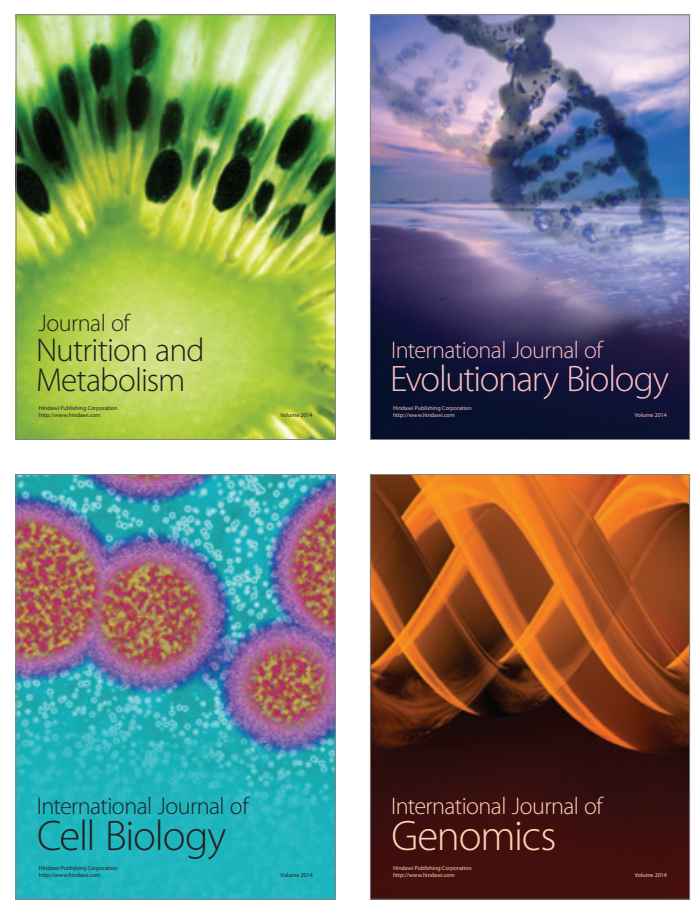
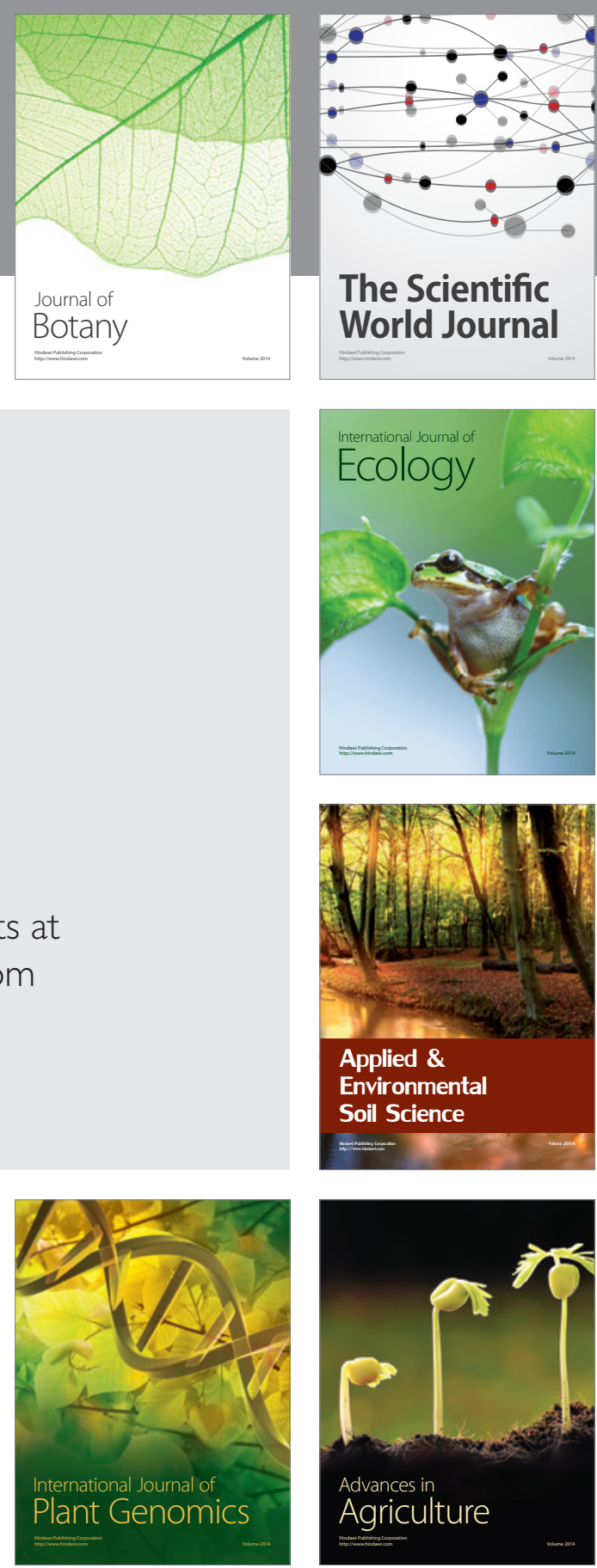

The Scientific World Journal
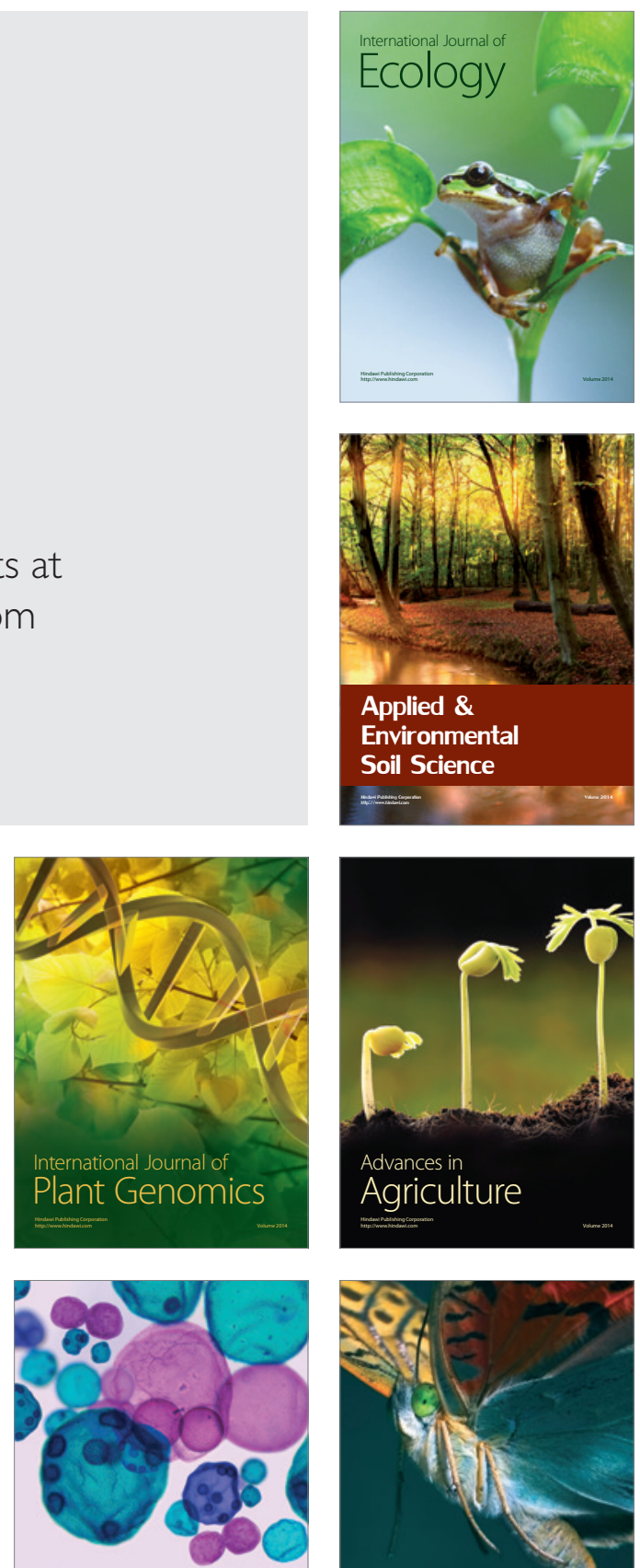

International Journal of Microbiology

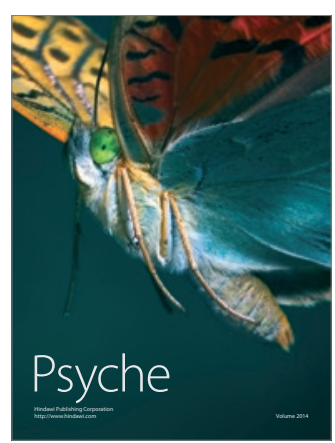

